\title{
ESSENTIAL OIL OF Protium unifoliolatum (BURSERACEAE)
}

\section{Maria das G. B. ZOGHBI', Emidio V. L. da CUNHA², Wilson WOLTER FILHO $^{1}$}

\begin{abstract}
The major constituents of the leaf essential oil of $P$. unifoliolatum are transcaryophyllene (37.45\%), limonene $(24.23 \%)$ and $\alpha$-humulene $(9.94 \%)$.
\end{abstract}

Key words: Burseraceae, Protium, Essential oils, Terpenes.

Óleo essencial de Protium unifoliolatum (BURSERACEAE)

RESUMO - O óleo essencial obtido das folhas frescas de $P$. unifoliolatum apresentou como constituintes principais trans-cariofileno (37,45\%), limoneno $(24,23 \%)$ e $\alpha$-humuleno $(9,94 \%)$. Palavras-chave: Burseraceae, Protium, Óleos essenciais, Terpenos.

\section{INTRODUCTION}

The trees or shrubs of the Burseraceae have in their bark prominent vertical schizogenous resin-ducts (containing triterpenoids compounds and ethereal oils) (CRONQUIST, 1981) which produce oil and gum-resins that are responsible by many of its medicinal properties (COSTA, 1975). This species are also used in perfumery industries (CRAVEIRO et al., 1981). The genus Protium known in Amazon region as "Breu" are utilized for boats sealing (Le COINTE, 1934) and in the confection of varnish (RIZZINI \& MORS, 1921); already was shown to contain essential oils. Essential oils from leaves of the $P$. heptaphyllum March. (RIZZINI \& MORS, 1921) and from the bark steam of $P$. paraense Cuatr. (GOTTLIEB et al., 1981) were already reported. Now we report the chemical composition of the essential oil from the leaves of $P$. unifoliolatum Engl. (Tab. 1).

\section{RESULTS AND DISCUSSION}

Gas chromatography/mass spectrometer obtained analysis revealed that the major constituents from the essential oil of the leaves of $P$. unifoliolatum were trans-caryophyllene, limonene and $\alpha$-humulene. The concentration of these compounds comprises $71.6 \%$ of the oil. From these compounds, limonene and $\alpha$-humulene are present in appreciable amount in the essential oil from the leaves of $P$. heptaphyllum (RIZZINI \& MORS, 1921). Identifications of the components was accomplished by comparison of mass espectra with Wiley/NBS library

1 Instituto Nacional de Pesquisas da Amazônia-INPA, Coordenação de Pesquisas em Produtos Naturais, Caixa Postal 478, 69011-970 - Manaus, Amazonas, Brasil.

2 Laboratório de Tecnologia Farmacêutica, Universidade Federal da Paraíba, 58059 - João Pessoa, PB, Brasil 
Table 1. Constituents of the essential oil of Protium unifoliolatum

\begin{tabular}{clr}
\hline Peak N & Compound & $\%$ of oilt \\
\hline 1 & $\alpha$-pinene & 0.63 \\
2 & B-pinene & 0.37 \\
3 & limonene & 24.23 \\
4 & $\alpha$-terpinolene & 1.25 \\
5 & benzoic acid, 2-hydroxy-methyl ester & 0.49 \\
6 & $\alpha$-copaene & 6.24 \\
7 & trans-caryophyllene & 37.45 \\
8 & $\alpha$-humulene & 9.94 \\
9 & B-cubebene & 2.14 \\
10 & eremophilene & 0.83 \\
11 & B-bisabolene & 0.64 \\
12 & $\delta$-cadinene & 0.87 \\
\hline
\end{tabular}

+ Relative to quantitation report of the data system

present at data system; retention data and Kovats Indexes.

\section{EXPERIMENTAL}

Plant material of $P$. unifoliolatum was collected in Manaus, state of Amazonas, during the raining season in 4/91. Fresh leaves were subjected to steam distillation according to current techinques (CRAVEIRO, 1976). The obtained oil was centrifuged together with anhydrous $\mathrm{Na}_{2} \mathrm{SO}_{4}$ and produced a yield of $0.11 \%$

The volatile oil was analyzed by $\mathrm{gc} / \mathrm{ms}$ at a Hewlett Packard system (chromatograph model 5890 and mass spectrometer model 5988), using a $25 \mathrm{~m}$ $\mathrm{x} 0.32 \mathrm{~mm}$ crosslinked methyl silicone gum, fused silica column. Helium was used as carrier gas. The temperature program was 85 to $180^{\circ} \mathrm{C}$ at $3^{\circ} \mathrm{C} / \mathrm{min}$ and then 180 to $250^{\circ} \mathrm{C}$ at $20^{\circ} \mathrm{C} / \mathrm{min}$. The ms was in EI mode at $70 \mathrm{eV}$.

The obtained spectra were compared to the spectra present at the Wiley/NBS Library which is part of our data system. All resulting spectra were stored on tape for latter recall.

\section{ACKNOWLEDGMENTS}

This study was funded by the Conselho Nacional de Desenvolvimento Científico e Tecnológico $(\mathrm{CNPq})$. We thank Mrs. Dionisio Coelho and Luis Coelho (INPA, Manaus) for the collection and Dr. Douglas Daly (New York Botanical Garden, USA) for botanical identification.

\section{Literature cited}

CRONQUIST, A. 1981. An Integrated System of Classification of Flowering Plants. Columbia University Press, New York p. 803.

COSTA, A. F. 1975. Farmacognosia, vol I, Fundação Calouste Gulbenkian, Lisboa, p. 906-959.

CRAVEIRO, A. A.; FERNANDES, A. G., ANDRADE, C. H. S.; MATOS, F. J. DE ABREU; ALENCAR, J. W. DE; MACHADO, M. I. L. 1981. Óleos essenciais de Plantas do Nordeste. Fortaleza. Edições UFC, p. 27-28.

CRAVEIRO, A. A.; MATOS, F. J.; ALENCAR, J.

W. 1976. A simple and inexpensive steam generator for essential oils extraction. $J$. Chem. Educ., 53:652.Le COINTE, P. 1934. A Amazônia Brasileira. III. Árvores e Plantas Úteis. Livraria Clássica, Pará, p. 64.

RIZZINI, C. T.; MORS, W. B. 1976. Botânica Econômica Brasileira. Editora da Universidade de São Paulo, São Paulo, p. 42.

GOTTLIEB, O. R.; KOKETSU, M.; MAGALHÃES, M. T.; MAIA, J. G. S.; MENDES, P. H.; ROCHA, A. I. DA; SILVA, M. L. DA; WILBERG, V. C. 1981. Óleos essenciais da Amazônia. VII. Acta Amazonica, 11(1):143. 